\title{
IMPLEMENTASI KEBIJAKAN PENGELOLAAN HUTAN PRODUKSI LESTARI DI KALIMANTAN TIMUR
}

\author{
Muhammad Zaini ${ }^{1}$ \\ Sarwo Eddy Wibowo ${ }^{2}$ \\ 1) University of Mulawarman \\ Jalan Kuaro No. 1 Gunung Kelua Samarinda, Kalimantan Timur, 75119, \\ Indonesia \\ mzaini@gmail.com \\ 2) University of 17 Agustus 1945 Samarinda \\ Jalan Juanda 80 Samarinda, Kalimantan Timur, 75124 Indonesia \\ eddibowo@gmail.com
}

(

\begin{abstract}
The Natural Production Forest Management (NPFM) policy in East Kalimantan has led to massive deforestation and degradation of East Kalimantan's natural forests. Until 2012, almost $70 \%$ of East Kalimantan's natural forest production has been damaged, more than that $80 \%$ of East Kalimantan's forestry business has gone bankrupt. While the ecological and social losses are not countless. This is inseparable form the weaknesses in the NPFM policy operating system.

In the perspective of administrative science, the effectiveness of NPFM policy implementation is related to the six administrative principles (Max Weber) in NPFM policy. The six neglected administrative principles are : 1) The principle of specialization of organizational functions, resulting in overlapping organizational functions Bureaucracy, Corporations and Operations in NPFM operation; 2) the formal hierarchical structure principle, as result there is no NPFM tiered supervision system; 3) Priciple of formal rules and standard operating prosedures (SOP), as a result, the NPFM deviation since the process of licensing, implementation and distribution of results; 4) Impersonal relationships, as a result bureaucratic decisions tend not to be objective; 5) The principle of special competence (professional), consequently the NPFM operation results are not optimal; 6) The principle of employing is in accordance with competence, consequently the NPFM performance is poor.
\end{abstract}

Keywords: NPFM Policy, Suistanable Forest, forest management

PENDAHULUAN

Hutan produksi merupakan

bagian dari sumber daya alam yang

dapat diperbaharuhi (renewable

resources), semestinya dikelola dengan bijak agar terjamin kelestarian fungsinya secara berkelanjutan. Degradasi hutan produksi, sebagai bagian dari hutan alam di Indonesia akan mempengaruhi fungsi hutan secara 
ekonomi dan ekologi hutan. Kerusakan hutan di bumi berdampak terganggunya keseimbangan fungsi ekologi dan ekosistem global. Gangguan fungsi ekologi dan ekosistem global saat ini ditandai dengan adanya perubahan iklim (climate change) dan peningkatan suhu rata-rata bumi yang kita kenal dengan pemanasan global (global warming). Saat ini manusia, hewan, iklim, tanah telah terkena dampak pemanasan global.

Kebijakan Pengelolaan Hutan Produksi Lestari (PHPL) yang tidak efektif dilaksanakan oleh unit-unit usaha kehutanan swasta pemegang IUPHHK (Izin Usaha Pemanfaatan Hasi Hutan Kayu), yang ada di Kalimantan timur khususnya dan umumnya di seluruh Indonesia adalah masalah serius. Penurunan produktivitas kayu dari hutan alam produksi secara terus menerus, kemerosotan Penerimaan Negara Bukan Pajak (PNBP) sektor kehutanan samapai titik terendah, dan PHK besar besaran dari sektor usaha sejak tahun 2003 sampai sekarang (2014), bahkan gulung tikarnya lebih dari $80 \%$ sektor usaha kehutanan adalah indikator adanya masalah besar dalam sektor usaha kehutanan.
Kebijakan Pengelolaan Hutan Alam Produksi Lestari (PHPL) yang selama ini pengoperasiannya diserahkan kepada unit manajemen swasta dengan melalui pemberian Izin Usaha Pemanfaatan Hasil Hutan Kayu (IUPHHK), telah membuka berbagai bentuk penyimpangan. Operasi kebijakan PHPL oleh swasta tanpa sistem administrasi yang layak untuk menjamin adanya akuntabilitas dan transparansi mulai dari perizinan, pelaksanaan, perdagangan/penjualan, dan pembagian hasil hutan membuat usaha kehutanan benar-benar tidak layak secara ekonomis, ekologis, maupun sosial. Semuanya telah berdampak buruk bagi praktek PHPL.di lapangan.

kehutanan memberikan kontribusi penting bagi perekonomian. Tercatat 3,6\% PDB Indonesia disumbang dari sektor kehutanan. Periode tahun 1988 1998 sektor industri kehutanan masih berkontribusi bagi penerimaan devisa rata-rata sebanyak $20 \%$ dari total penerimaan devisa negara (Kartodirdjo,1999). Namun dalam waktu yang bersamaan hutan alam Indonesia mengalami kerusakan secara besar-besaran dalam waktu yang relatif singkat. 
Secara administrasi, kebijakan PHPL juga dihadapkan pada permasalahan dengan kebijakan sektor lain. Hal ini terbukti dengan belum adanya integrasi (keterpaduan) dan harmonisasi antar kementerian terkait. Salah satu indikator adanya masalah ini adalah Rencana Tata Ruang dan Wilayah (RTRW) Kalimantan Timur yang sudah selama dua periode pemerintahan 2004-2009 dan 20092014 belum mendapat pengesahan dari pemerintah pusat. Namun kenyataan di lapangan, alih fungsi kawasan hutan di Kalimantan Timur untuk area kegiatan usaha non kehutanan seperti pertambangan, perkebunan, dan pertanian dan lain-lain berjalan terus. Berdasarkan paparan uraian pada latar belakang penelitian ini, maka dalam penelitian ini mengangkat judul "Implementasi Kebijakan Pengelolaan Hutan Produksi Lestari di Kalimantan Timur".

1. Bagaimana Implementasi kebijakan Pengelolaan Hutan Produksi Lestari (PHPL) di Kalimantan Timur, memenuhi kelayakan sebagai Sistem Pengendalian Intern (SPI) untuk menjamin efektivitas pelaksanaan kebijakan PHPL?
2. Apakah implementasi kebijakan pengelolaan Hutan Produksi lestari efektif dalam pengelolaan hutan produksi di Kalimantan Timur?

\section{KERANGKA TEORITIS}

Manajemen Hutan Lestari

\section{(Sustainable Forest Manajemen)}

Kesadaran terhadap adanya ancaman kepunahan hutan dan kompleksitas permasalahan sosial, ekonomi dan budaya setempat terkait usaha pelestarian hutan, mendorong tumbuhnya konsep tentang manajemen hutan lestari. Manajemen hutan lestari (Sustainable Forest Manajemen) dibangun untuk mengatasi masalah kontradiksi fungsi sosial, ekonomi, ekologi hutan. Sehingga manajemen hutan lestari harus mengakomodasi kepentingan masyarakat lokal, kepentingan bisnis kehutanan dan kepentingan ekologi secara harmonis dan seimbang.

Manajemen hutan lestari merupakan konsep pengelolaan hutan yang menjaga fungsi ekologis dan fungsi ekonomi hutan secara berkelanjutan. Manajemen hutan lestari di Indonesia masih berorientasi sebagai teknik mengelola hutan untuk mengambil manfaat ekstrinsik langsung hutan berupa kayu yang nilainya tidak 
lebih dari 5\% total hasil. hutan (Sutisna, 2008). Bahkan menurut hasil penelitian IPB (1999) nilai ekstrinsik langsung hutan berupa kayu dan hasil hutan non kayu hanya 4,5\% dari total nilai hutan. Pengusahaan hasil hutan yang hanya berorientasi manfaat ekstrinsik langsung tidak memenuhi kriteria layak secara ekonomis (Mamat, 2010)

Salah satu faktor kegagalan pengelolaan hutan adalah kelemahan kebijakan dalam operasi kebijakan PHPL. Sistem kebijakan PHPL yang ada tidak ada Sistem Pengendalian Internal (SPI) dalam rangka mengamankan hak-hak Negara, hak masyarakat dan melestarikan fungsi ekologi hutan. Ketentuan administrasi perizinan yang tidak sesuai prinsip.

\section{Kebijakan Pengelolaan Hutan Alam}

\section{Produksi Lestari (PHPL)}

Kebijakan pengelolaan hutan alam sebagai hutan produksi yang dikeluarkan pemerintah Indonesia yang tertuang dalam kebijakan silvikultur PHPL (Pengelolaan Hutan Alam Produksi Lestari) mencerminkan bahwa orientasi kebijakan kehutanan Indonesia masih berorientasi pada pengelolaan hasil hutan yang tidak lebih dari $5 \%$ tersebut.
Manajemen hutan lestari yang dibangun Pemerintah Indonesia dituangkan dalam kebijakan silvikultur PHPL, merupakan rangkaian keputusan dan peraturan pemerintah dalam mengelola kawasan hutan alam yang ditetapkan sebagai hutan produksi. Manajemen kebijakan pengelolaan hutan alam produksi lestari dimulai dari kebijakan perizinan usaha Kehutanan, kebijakan silvikultur untuk pengelolaan hutan produksi dan kebijakan penataan organisasi dan prosedur tata usaha hasil hutan.

Operasi kebijakan PHPL untuk pengelolaan hutan alam produksi lestari yang perlu dikontrol meliputi; (1) sistem perizinan (2) sistem silvikultur dan teknik pemanenan (logging), (3) penata-usahaan hasil hutan yang berupa produksi (kayu dan non kayu) dan (4) perdagangan/ distribusi hasil hutan.

Sesuai amanat Konstitusi, pasal 33 ayat 3 UUD 1945. Keberadaan BUMN Kehutanan sebagai lembaga Korporasi Kehutanan Negara yang bertanggungjawab menjalankan regulasi dan kebijakan PHPL yang dibuat oleh Kementerian Kehutanan. Untuk itu BUMN Kehutanan kehutanan bertanggungjawab menjalankan peraturan kebijakan kehutanan, untuk 
mengelola dan memanfaatkan hutan sebagai sumber daya strategis milik Negara untuk kesejahteraan rakyat dan menghasilkan keuntungan.

Untuk profesionalitas, akuntabilitas, dan transparansi pengelolaan sumberdaya hutan bagi kepentingan bangsa dan negara, selanjutnya PT PERHUTANI bersinergi dengan lembaga pelaksana kebijakan PHPL, untuk melimpahkan sebagian kewenangan pengelolaan hutan produksi secara lestari kepada unit-unit operasi usaha kehutanan yang secara professional. Lembaga profesional pelaksana (operator) kebijakan PHPL bisa dibentuk oleh negara, maupun unit-unit operasi usaha kehutanan swasta yang telah ada. Dengan demikian efektivitas dan efisiensi, pengelolaan hutan alam produksi lestari secara ekonomi, ekologi dan sosial bisa ditingkatkan.

\section{Kebijakan silvikultur}

Untuk mewujudkan sasaran kebijakan PHPL maka Kemenhut Mengembangkan Kebijakan sistem Silvikultur PHPL. Silvikultur merupakan ilmu dan seni untuk mengelola tegakan hutan melalui pembangunan dan pengendalian tegakan, pertumbuhan, struktur dan komposisi tegakan, dan kualitas tegakan sesuai degan tujuan pengelolaan hutan yang ditetapkan (Sutisna, 2008). Sistem silvikultur sesuai Peraturan Menteri Kehutanan No. P. 11/Menhut-II/2009, adalah sistem pemanenan sesuai tapak/tempat tumbuh berdasarkan formasi terbentuknya hutan yaitu proses klimatis dan edafis dan tipe-tipe hutan yang terbentuk dalam rangka pengelolaan hutan lestari. Sistem silvikultur merupakan subsistem pengelolaan hutan, untuk menjamin kelestarian ekosistem hutan yang meliputi :

a. Seni memproduksi hutan.

b. Penerapan pengetahuan silvika dalam perlakuan-perlakuan terhadap hutan.

c. Teori dan praktek pengendalian pembangunan hutan.

\section{METODE PENELITIAN}

Metode analisis dalam penelitian ini menggunakan metode analisis deskriptif kualitatif dan. Data primer dan data sekunder yang telah terkumpul diverifikasi, disusun dan diolah dan dianalisis untuk menjawab permasalahan yang ada dalam penelitian. Adapun obyek penelitian 
ini Dinas Kehutanan di Kaltim yang merupakan administrator kebijakan PHPL yang dibuat pemerintah. Laporan hasil pengelolaan HPH/IUPHHK aktif yang ada pada Dinas Kehutanan Provinsi Kalimantan Timur. Teknik pengumpulan data yang digunakan dalam penelitian ini adalah teknik observasi, studi dokumen, wawancara tersetruktur, dan angket. Adapun data yang diperoleh terdiri atas :

a. Data sekunder

Data sekunder dikumpulkan dari sumber-sumber Kementerian Kehutanan, dari buku laporan Dinas Kehutanan Propinsi dan Kabupaten/kota, Biro Pusat Statistik Kaltim, dan laporan dari lembaga pemerintah serta informasi/laporan tahunan dari unit-unit manajemen IUPHHK di Kaltim.

b. Data Primer.

Pengambilan data primer dilakukan dengan interview terhadap informan dari unsur-unsur stakeholder dalam pelaksanaan kebijakan PHPL, mulai dari unsur birokrasi, korporasi dan operator di lapangan. Data primer diperoleh melalui wawancara mendalam dengan para pihak terkait dalam operasi kebijakan PHPL dalam usaha kehutanan, dengan menggunakan menggunakan daftar pertanyaan dan diskusi dengan stakeholder yang berada di obyek penelitian.

\section{ANALISA DAN PEMBAHASAN}

Kebijakan Admininistrasi

PHPL yang meliputi Penataan organisasi/kelembagaan,

perencanaan, mekanisme perizinan, sistem silvikultur, tatausaha/tataniaga hasil hutan, dan pengawasan/ pengendalian dalam pengelolaan sumber daya hutan yang diamanatkan negara untuk dikelola dg lestari guna mewujudkan masyarakat adil, makmur dalam wadah Negara Kesatuan Republik Indonesia sesuai PP No 5 Th 2007 menunjukkan kelemahan mendasar sebagai berikut :

\section{Kelemahan Sistem Organisasi}

\section{(Kelembagaan/Institusi PHPL)}

Sebuah usaha yang professional perlu ada unit-unit organisasi spesifik yang memisahkan fungsi negara sebagai pemilik ( regulator) fungsi pengelola (administrator) dan fungsi pelaksana 
(operator). Dalam sistem organisasi pengusahaan hutan permasalahannya pemisahan fungsi, sebagai sistem pengendalian bisnis kehutahan belum ada dan belum diberdayakan:

1. Fungsi regulator dijalankan organisasi Negara dengan yakni Birokrasi yakni KEMENHUT: Sebagai pengambil kebijakan, pembuat peraturan (regulator), jangan mengurusi soal lain, agar tidak terjadi konflik kepentingan.

2. Fungsi administrator dijalankan BUMN di bawah KEMENTERIAN BUMN yang bergerak di bidang usaha kehutanan: Sebagai administrator BUMN kehutanan bertanggungjawab melaksanakan kebijakan dan peraturan kehutanan yang berlaku, memanfaatkan dan memberdayakan sumber daya hutan yang dipercayakan untuk dikelola dalam rangka mencapai tujuan yang telah ditentukan yakni pengelolaan hutan produksi lestari (PHPL).

3. Fungsi Operator Usaha kehutanan, yakni Unit-unit organisasi Manajemen HPH/IUPHHK: sebagai pelaksana dibawah kendali pemerintah melalui kementerian BUMN yang bertanggungjawab penuh mengoperasikan usaha kehutanan guna mewujudkan kebijakan PHPL di lapangan.

4. Fungsi organisasi pengawas usaha kehutanan, yakni lembaga pengawas independen (LPI) lembaga swadaya masyarakat dan lembaga negara terkait seperti BPK, KPK.

Implementasi hutan produksi lestari tidak memenuhi unsur administrasi sebagai SPI, ditambah lagi kelemahan organisasi birokrasi dan korporasi, juga adanya fungsi yang tumpang tindih (overlapping) antara fungsi birokrasi dan korporasi, menjadi peluang korupsi bagi para birokrat dan korporat pada semua tingkat.

Kelemahan administrasi perizinan (IUPHHK) nampak pada ketentuan keterlibatan kepala daerah dalam memberikan rekomendasi perizinan usaha kehutanan, batas waktu keluarnya izin yang tidak jelas dan biaya penerbitan izin yang tidak transparan. Semua itu merupakan bagian dari celah-celah yang dimanfaatkan oknum pejabat dan 
birokrat terkait untuk memungut biaya tidak resmi (korupsi) yang jumlahnya mencapai 70 s.d. $80 \%$ dari total pungutan yang dibayar unit manajemen UPHHK (Anonym, 2012). Menurut kajian KPK (2014) masih ada 20 celah dalam administrasi perizinan usaha kehutanan yang membuka peluang timbulnya biaya tidak resmi (korupsi).

\section{Pemerintah (Kemenhut)} sebagai representasi Negara pengemban amanah mengurus dan mengusai sumber daya hutan alam, seharusnya berperan dalam pembuatan sistem administrasi dan kebijakan PHPL yang layak secara ekologi,ekonomi dan sosial. Dalam prakteknya kemenhut sebagai birokrasi yang seharusnya sebagai regulator, merangkap fungsi sebagai korporasi yang menjalankan peran administrator usaha kehutanan yang pencari keuntungan, sekaligus pengawas (supervisor) operasi usaha kehutanan tanpa dilengkapi organisasi penunjang efektivitas fungsi-fungsi yang seharusnya ditangani secara terpisah dan professional. Perizinan usaha kehutanan juga masih didominasi
Izin Usaha Pemenafaatan Hasil Hutan Kayu (IUPHHK) oleh pihak swasta yang bersifat sementara (20 tahun). Perusahaan Negara kurang banyak berperan dalam operasi usaha kehutanan.

Sistem administrasi perizinan yang seharusnya hanya memberikan IUPHHK kepada unit-unit manajemen yang berkomitmen dan profesional menjalankan kebijakan PHPL untuk mewujudkan tujuan kebijakan PHPL ternyata tidak mencapai tujuan. Unit-unit manajemen IUPHHK yang tidak profesiaonal dan berkomitmen mewujudkan PHPL bisa mendapat konsesi IUPHHK. Akibatnya mereka tidak menerapkan kebijakan PHPL dalam mengelola hutan.

Administrasi kebijakan PHPL seharusnya secara ilmiah memenuhi syarat kelayakan sebagai Sistem Pengendalian Internal (SPI) sebagaimana dikemukakan Mulyadi $(2009 ; 166)$ kenyataannya belum berfungsi. Administrasi kebijakan PHPL yang ada belum memenuhi 5 unsur SPI sebagai berikut :

1. Struktur organisasi membagi tugas dan fungsi 
2. Pemisahan tanggung jawab fungsional;

3. Sistem wewenang dan prosedur pencatatan yang memberikan perlindungan keamanan transaksi;

4. Praktek yang sehat dalam melaksanakan setiap fungsi;

5. Karyawan profesional sesuai dengan tanggung jawabnya.

Administrasi kebijakan PHPL yang ada belum memenuhi prinsipprinsip administrasi yang efektif menurut Weber, dalam Wartiningsih (2010), yang mana seharusnya memenuhi enam (6) prinsip administrasi yang baik yakni:

Prinsip pembagian kerja kepada organisasi (secara terpisah):

1. Prinsip jenjang hierarkhi posisi (setiap posisi bawahan diperintah dan dikontrol oleh atasan; sehingga ada sistem rantai kontrol;

2. Aturan formal yang mengatur perilaku pekerja secara dengan standard, yang menjamin kepastian lingkungan dan performa kerja;

3. Hubungan impersonal yang meniadakan ikatan emosional atasan bawahan, untuk menjamin kejelasan posisi;
4. Kompetensi khusus dan latihan untuk menempati kedudukan administratif (dengan seleksi ketat administrator agar tidak ada pengangkatan dan pemberhentian suka-suka);

5. Mempekerjakan karyawan berdasarkan kompetensi (untuk menciptakan kinerja individu dan organisasi.

6. Hasil operasi kebijakan silvikultur PHPL di Kaltim tercermin pada indikator sebagai berikut:

a. Penerimaan Negara Sektor Kehutanan

b. Berbagai pungutan yang dikenakan pada sektor kehutanan ada 8 jenis, yakni : a. IIUPH (Iuran Ijin Usaha Pemanfaatan Hutan); b. DR (Dana Reboisasi); c. PSDH (Provisi Sumberdaya Hutan); d. PBB (Pajak Bumi dan Bangunan); e. PPh (Pajak Penghasilan); f. PPN (Pajak Pertambahan Nilai); g.Ganti rugi tegakan; h. Iuran Hasil Hutan. S ebagai perbandingan di Negara lain pungutan usaha kehutanan di Negara lain paling banyak dua pungutan. 
Pungutan yang dikenakan tanpa memperhitungkan rasionalitas dan kemampuan finansial unit usaha, sehingga sangat membebani pengusaha. Akibatnya menurut APHI (Asosiasi Pengusaha Hutan Indonesia) profitabilitas sektor usaha kehutanan mendekati 0 , (harga jual $=$ harga pokok) . Pungutan/iuran sector kehutanan tersebut tidak dikembalikan ke usaha untuk pembangunan kembali hutan yang rusak.

c. Selain tarif pajak dan pungutan resmi kehutanan, maka pungutan tidak resmi menurut nara sumber dari unit-unit manajemen di tempat penelitian (Anonim, 2012) jumlahnya lebih besar dari tarif pajak dan pungutan resmi. Sehingga beban biaya yang memberatkan sektor usaha kehutanan yang mengancam kelestarian hutan dan kelestarian usaha kehutanan. Tujuan meningkatkan pendapatan negara dari sektor kehutanan dengan aneka pungutan tidak berhasil mencapai tujuan. Penurunan PNBP adalah akibat banyaknya sektor usaha kehutanan yang gulung tikar (jatuh pailit) yakni lebih dari $80 \%$ usaha kehutanan gulung tikar. Banyaknya usaha kehutanan gulung tikar karena merosotnya produktivitas hasil hutan kayu, dan kemerosotan produktivitas kayu tersebut diakibatkan persediaan kayu hutan alam makin menipis. Menipisnya persediaan kayu hutan alam akibat hutan alam dieksploitasi melebibihi daya dukung lestari (overeksploitation) baik dengan legal logging maupun illegal logging.

Pungutan sektor usaha kehutanan yang besarnya tidak rasional, melampaui batas (overcost), yang terdiri dari 8 item tersebut, ditambah pungutan tidak resmi . Di mana menurut ketua APHI (Suparna,2013) total pungutan sektor usaha kehutanan mencapai 20-30\% dari biaya produksi, dan hasil informasi dari pelaku usaha pada unit-unit manajemen, pungutan tidak resmi jauh lebih besar dari pungutan resmi, mencapai $70-80 \%$ dari total 
pungutan yang harus di bayar perusahaan. Aneka pungutan yang tidak proporsional tersebut telah mengorbankan biaya untuk kelestarian hutan alam.

Undang-undang Nomor 32 Tahun 2009 tentang Perlindungan dan Pengelolaan Lingkungan Hidup telah mengamanatkan bahwa untuk menjaga kelestarian fungsi lingkungan hidup dan keselamatan masyarakat, setiap perencanaan tata ruang wilayah wajib didasarkan pada Kajian Lingkungan Hidup Strategic (KLHS), dan ditetapkan dengan memperhatikan daya dukung dan daya tampung lingkungan hidup.

Tidak efektifnya tujuan kebijakan eksploitasi hutan alam secara ekologi termanifestasi berupa terganggunya siklus hidrologi dengan peningkatan aliran air di permukaan tanah pada waktu hujan, dan fluktuasi debit air sungai yang sangat tajam antara musim hujan dan kemarau, peningkatan intensitas dan frekuensi bencana ekologis seperti banjir, erosi, dan penurunan kesuburan tanah, peningkatan sedimentasi yang menurunkan kualitas air sungai, mengancam kelestarian keanekaragaman hayati (flora dan fauna) dan terjadinya perubahan iklim mikro. Adapun perhitungan secara rinci tidak efektifnya kebijakan PHPL sebagai berikut:

\section{Gangguan Fungsi Hidrologi}

Fungsi hidrologi yang terganggu sebagai dampak eksploitasi hutan adalah penurunan kemampuan hutan mengatur tata air, di mana hutan mampu mengurangi laju aliran permukaan pada saat hujan, menyimpan dalam bentuk air tanah dan mengalirkan air hujan secara relatif stabil ke sungaisungai, mata air dimusim kemarau sehingga tidak terjadi kekeringan (krisis air) dimusim kemarau. Beberapa hasil kajian ilmiah menyatakan bahwa dalam hutan tropika basah terjadi kenaikan simpanan air tanah sebanyak $10 \%$ dan penurunan simpanan air sebagai reaksi terhadap pemanenan kayu berbanding lurus dengan jumlah tajuk yang hilang. Sementara aliran permukaan akan berkurang sejalan dengan pertumbuhan hutan tersebut menjadi keadaan seperti semula sebelum pemanenan

\section{Peningkatan Erosi Tanah}

Erosi tanah tidak akan menjadi masalah signifikan pada daerah yang kondisi hutannya masih baik. Erosi tanah adalah akibat eksploitasi hutan 
kayu yang menurunkan strata tajuk tegakan, tumbuhan bawah, tumbuhan pemanjat, dan seresah yang kesemuanya memberikan perlindungan terhadap tanah dari dampak air hujan yang tercurah. Tidak adanya perlidungan hutan terhadap tanah berpotensi besar meningkatkan erosi, apalagi adanya limpasan air yang cukup besar di daerah hujan tropis

\section{Penurunan Kesuburan Tanah}

Dalam mata rantai ekosistem hutan berfungsi dalam menjaga stabilitas kesuburan tanah. Selama hutan dalam keadaan lestari tanpa gangguan berarti, maka siklus zat hara dalam ekosistem hutan berlangsung tertutup (closed mineral cycling) karenanya kesuburan tanah di bawah vegetasi hutan dapat dipertahankan dan berlangsung lama. Siklus zat hara dalam hutan akan terputus, bilamana hutannya mengalami pemanenan tanpa mempertimbangkan daya dukung lestari dan sistem silvikultur yang salah dan berakibat keseluruhan pohon ditebang habis. Atau dialih fungsi untuk penggunaan lain seperti perkebunan, hutan tanaman, pertanian dan sebagainya.

\section{Peningkatan Sedimentasi}

Sedimentasi

(pengendapan) dipahami sebagai terangkutnya unsurunsur tanah yang terbawa oleh oleh limpasan air atau aliran air permukaan, yang selanjutnya mengendap pada suatu tempat karena kecepatan alirannya melambat atau terhenti pada saluran air, sungai, waduk, danau maupun kawasan tepi teluk/laut. (Arsyad 1989). Erosi dapat mempengaruhi kesuburan tanah yang bisanya mendominasi DAS bagian hulu dan dapat memberikan dampak negatif berupa pendangkalan pada DAS bagian hilir (sekitar muara sungai) yang berasal dari hasil sedimentasi.

Penebangan hutan dari segi hidrologi akan meningkatkan sedimentasi dan perubahan pola aliran sungai. Pengaruh negatifnya terhadap DAS mengakibatkan sedimentasi di sungai yang akan berdampak pada daerah hilir. Sumber utama endapan terutama berasal dari erosi berat yang terjadi pada jalan angkutan, jalan sarad, tempat pengumpulan kayu, tempat penimbunan kayu dan tempat-tempat penyeberangan yang tertimbun tanah. Laporan Hamzah (1978) dalam supriadi (2012) menunjukkan terjadinya peningkatan kandungan lumpur pada bagian sungai yang letaknya dekat 
dengan daerah eksploitasi kayu di Kalimantan Timur.

\section{Penurunan Keanekaragaman Hayati}

Hutan hujan tropis merupakan gudang bagi penyimpan keanekaragaman hayati.Laporan WWF (2012) setiap $1 \mathrm{~km} 2$ hutan Kalimantan Timur yang masih virgin (di Malinau) mengandung tidak kutang dari 15.000 jenis vegetasi, 6000 vegetasi endemik, termasuk 155 jenis dipterokarpa. Kekayaan vegetasi Kalimantan Timur merupakan tertinggi di dunia. Penebangan hutan akan berdampak pada hilang atau rusaknya habitat bagi keanekaragaman hayati (biodiversity) baik vegetasi maupun satwa liar. Penebangan hutan akan mengakibatkan kerusakan yang terlalu berat pada vegetasi, berdampak sulitnya pemulihan kembali dan menyebabkan kualitas dan produktifitas hutan menurun. Pemanenan kayu dari hutan tropis telah memberikan keuntungan sosial ekonomi bagi manusia, sekaligus menimbulkan masalah lingkungan. Penebangan hutan akan mengakibatkan perubahan kondisi biologis dan habitat dari kondisi hutan awal yang tidak dapat dihindari. Berbagai species yang secara ekonomi mungkin lebih penting dari pada kayu yang hilang atau punch.
Beberapa hasil penelitian menunjukan dampak eksploitasi hutan terhadap penurunan keanekaragaman satwa liar, karena eksploitasi hutan berakibat berkurangnya kelimpahan makanan dan habitat bagi satwa liar berkembang biak.

\section{Perubahan iklim mikro}

Deforestasi sering diposisikan sebagai penyebab signifikan terjadinya perubahan iklim makro, meskipun emisi $\mathrm{CO} 2$ lebih banyak berasal dari kegiatan pembakaran bahan bakar fosil. Hutan dengan kandungan biomass yang tinggi memiliki peran dalam mempengaruhi iklim mikro, peran tersebut diantaranya: (1)Kemampuan hutan menyerap dan menyimpan Karbon (C) yang ada di atas tanah melalui seluruh bagian tubuh pohon, karbon pada permukaan tanah yang ada pada humus dan seresah, serta karbon yang ada di bawah tanah (perakaran dan karbon pada tanah), (2) Kemampuan menghasilkan Oksigen (O2) yang dilepas ke atmosfir, dan menghasilkan emisi karbon hasil penebangan pohon, konversi hutan, kebakaran hutan (3) hutan juga memiliki kemampuan menyerap Karbon (dengan mengurangi emisi GRK) melalui 
photosintesa (pepohonan menyerap

karbon (C02) di siang hari.

\section{Temuan Masalah Implementasi}

\section{Kebijakan PHPL}

Implementasi PHPL lebih dikuasakan pada KPH. Apabila dikaji dari hubungan relasi antara Kesatuan Pengelolaan Hutan (KPH) dan korporasi selama ini merupakan mitra yang bekerjasama dalam kegiatan perhutanan di Indonesia. KPH dalam PP no. 6 tahun 2007 memberikan peranan yang luas mencakup KPH yang merupakan wilayah pengelolaan hutanyang memiliki tugas kesatuan pengelolaan hutan yang mencakupperencanaan dan pengeloaan yang meliputi rehhabilitasi , perlindungan, pemeliharaan, dan pemanfaatan.

KPH memiliki 3 fungsi sebagai teknis penyelenggaraan tata kelola hutan, fungsi manajerial terkait perencanaan hingga evaluasi kebijakan hutan, fungsi bisnis mendorong investasi korporasi untuk hadir dalam menanamkan modal di hutan. Fungsi bisnis mendorong KPH bermitra dengan korporasi melalui sebuah forum FGD (focus Grup Discussion). Selama ini korporasi besar telah melakukan kegiatan penebangan kawasan hutan produksi lesatri untuk memanfaatkan sumber daya hutan menjadi barangbarang yang diutuhkan oleh masyarakat luas hingga di ekspor ke mancanegara. $\mathrm{KPH}$ perlu bekerjasama dengan korporasi dan meletakkan kesepakatan bahwa selain di eksplorasi hutan harus di tanam kembali. Hal ini sesuai dengan tujuan dari KPH yakni mengelola hutan secara lesatri dan memberikan manfaat bagi masyarakat di dalam dan sekitar kawasan hutan. Namun hal ini belum tentu akan terlaksana mengingat problematika eksplorasi hutan membawa keuntungan bagi satu pihak semata, di lain pihak banyak masyarakat yang dirugikan. Mengingat riset ini mengacu pada KPHP kesatuan pengelolaan hutan produksi maka wilayah hutan yang menjadi prioritas didonminasi oleh kawasan hutan produksi yang memproduksi hasil hutan kayu.

Keberadaan petugas KPHP di lapangan terkadang memiliki kesalahpahaman. Masyarakat menganggap bahwa keberadaan petugas KPHP yang menyusuri hutan produksi merupakan oknum yang menjadi ancaman bagi mereka karena akan mengusik mata pencaharian masyarakat sehari-hari. Masyarakat perlu adanya 
sosialisasi dan diskusi agar keberadaan Petugas KPHP di lapangan adalah pihak yang akan mebantu terlaksananya pemanfaatan hutan yang berguna bagi masyarakat sekitar dan membawa dampak ekonomi dan kesejahteraan. KPHP dan Korporasi mengupayakan kegiatan pengelolaan desa dalam hal pembiayaan community development dengan menggagas tata kelola lokasi untuk pengembangan ekonomi masyarakat. Hal ini diimplementasikan melalui serangkaian kegiatan yang dimotori oleh tokoh setempat.

Selama ini tata kelola hutan belum maksimal sehingga hutan bila di eksplorasi secara tidak terkendali akan mengalami degradasi dan deforsrtrasi sehingga muncul masalah lingkungan yang perlu penaganan serius. KPH yang mnerupakan lembaga yang melaksanakan kegiatan pengelolaan hutan perlu memperhatikan eksistensi $\mathrm{KPH}$ diperlukan masyarakatsebagai mediasi apabila terjadi konflik yang terjadi, KPH juga dapat memberikan hak akses bagi masyarakat apabila masyarakat ingin sumber daya hutan, korporasi yang emnanamkan modal atau melakukan kegiatan eksplorasi dapat di audit dan pelru kejelasan investasi yang dilakukan selama ini.
$\mathrm{KPH}$ perlu menggerakan dan memberdayakan Masyarakat sebagai wujud kemitraan dan fasilitator untuk menggali potensi sumber daya hutan. Pemerintah memberikan SK hutan tanaman legal. Walaupun ada konflik namun aturan diarahkan untuk diselesaikan secara bersama. KPH melakukan Manajemen dan tata kelola hutan hal ini dapat kita lihat di tugas pokok dan fungsi KPH yang meliputi :

1. Tata hutan dan penyusunan rencana pengelolaan hutan

2. Pemanfataan hutan dalam hal pemantauan dan pengendalian terhadap pemegang ijin

3. Rehabilitasi hutan dan reklamasi

4. Pemanfatan hutan di wilayah tertentu

5. Perlindungan hutan dan konservasi alam

Berdasarkan tugas pokok fungsi di atas, KPH memiliki tugas pokok dan fungsi secara terstruktur untuk mengelola dan mengevaluasi kegiatan hutan di lapangan. Namun praktek di lapangan yang berbicara ketika pihak $\mathrm{KPH}$ terjun dan mengalami sendiri kegiatan hutan di lapangan masih banyak yang belum sesuai antara kebijakan tata kelola dan kendala yang dihadapi di lapangan. 
Tata hutan dan penyusunan rencanapengelolaan hutan bagi pihak KPH perlu dikajisecara mendalamkarena halini juga memiliki eterhubungan dengan berbagaipihak terutama perusahaan yang akanmelaksanakanRKT (rencanakerja tahunan). Perusahaan perlu melakukan kegiatan laporan rencana dan realisasi yang telah dilakukan baik perusahaan yang telah HTI dan hutan produksi. Hutan produksilestari merupakan hutan yang dapat dimanfaatkan hasil alamnya namun jangan sampai terjadi overlapping yang menyebabkan hutan menjadi gundul dan berakibat pada bencana dan kerusakan alam. Pemantauan dan pengendalian yang dilakukan oleh jajaran pemerintah baik di bawah kementerian, Dinas kehutanan Provinsi, Dinas Lingkungan Hidup Provinsi, hingga masyarakat sekitar akan membantu proses monitoring dan evaluasi. Namun apabiladikaji ke lapangan kegiatan monitoring dan pemantauan terkadang memiliki kelemahan terkait proses kegiatan dan kewenangan yang tumpang tindih.

Pemanfataan hutan dalam hal pemantauan dan pengendalian terhadap pemegang ijin HPH atau para pengusaha hutan telah dilakukan dengan bekerjasama dengan LSI (lembaga standarisasi Indonesia) yang merupakan lembaga independen yang bekerjasama dengan lembaga akreditasi KAN (Komite Akreditasi Nasional) . Dinas kehutanan provinsi secara proporsional bekerjasma dengan LSI melakukan tata kelola manjaemen hutan dan melaksnakan pendataan.

Saat ini hutan di Kalimantan mengalami masa-masa kritis akibat penebangan liar dan illegal logging akibat pembukaan lahan yang terjadi secara besar-besaran. Hutan perlu kebijakan dalam pengelolaannya bukan hanya untuk dimanfaatkan semata namun perlu dilakukan melalui kegiatan rehabilitasi hutan dan reklamasi Perlindungan hutan dan konservasi alam. Hal ini berguna untuk mencegah bencana alam dan tetap menjaga kelestarian alam. Pemerintah melalui dinas kehutanan Provinsi mewajibkan para pengusaha hutan untuk terus melaporkan rencana kerja tahunan perusahaanm mulaidari perencanaan hingga realisasi yang terjadi dalam kurun waktu 1 tahun.

Hutan alam RHU yang terdapat pada 1 peta akan di audit pemantauannya melalui Dirjen 
kementerian yang terdiri dari 13 dirjen diantaranya :

1. Sekjen KLHK

2. Planologi kehutanan dan tata lingkungan

3. Konservasi sumber daya alam dan ekosistem

4. Pengendalian Daerah Aliran sungai dan hutan lindung,

5. Pengelolaan hutan dan produk lestari

6. Pengendalian pencemaran dan kerusakan lingkungan

7. Pengelolaan sampah, limbah, dan B3

8. Pengendalian perubahan iklim

9. Perhutanan sosial dan kemitraan lingkungan,

10. Penegakan hokum lingkungan hidup dan kehutanan,

11. Irjen KLHK,

12. Badan pengembangan SDM,

13. Badan penelitian pengembagan dan inovasi KLHK

Dipihak lain ada UPT kementerian yang memantau secara teknis di lapangan. UPT Kementerian bersama $\mathrm{KPH}$, dinas, dan masyarakat akan mengelola dan memantau akses informasi. Mediasi, dan kegitankegiatan terkait aturan hutan adat serta klaim yang terjadi di lapangan.
Beragam masalah dan konflik dapat terjadi dilapngan salah satuya adalah klaim masyarakat sekitar mengenai hutan adat leluhur yang secara eksplisit dilakukan masyarakat lokal dan di dukung oleh LSM misalnya saja yang terjadi di HPL DAS Belayan yang dimotori oleh LSM Masyarakat Adat Nusantara dan NGO asing yang turut mendampingi masyarakat dalam advokasi. Pada segi manajemen terutama manajemen kontrol, $\mathrm{KPH}$ (Kesatuan pengelolaan Hutan) masih belum detail kecuali dari provinsi ada pelimpahan hak. Wewenang utama mengenai tata kelola hutan terpusat pada Dinas Kehutanan Provinsi karena secara keseluruhan didominasi oleh hutan konservasi dan hutan produksi lestari sehingga wilayah kerjanya lintas provinsi. Dinas Kehutanan Provinsi dan $\mathrm{KPH}$ melakukan pendataan dan mendampingi semua lapisan masyarakat sebagai komitmen untuk mempecepat pembangunan hutan di daerah-daerah.

Hutan produksi lestari berusaha untuk menjamin kayu yang ditebang melalui serangkaian aktivitas legal melalui pengelolaan hutan. Sifatnya yang produktif dan memiliki tingat verifikasi yang tinggi dalam pemanfataan kayu bagi pemegang ijin 
dan hak pengelolaan hutan. Wujud hutan produksi lestari terdapat jalur aturan baku dalam tebang pilih agar tidak terjadi penyalahgunaan dan pembabatan secara liar. Prinsip tebang pilih tanam merupakan konsep produksi lestari yang memiliki dampak positif bagi pemulihan kondisi alam melalui target aturan yang berlaku.

\section{KESIMPULAN}

Hasil penelitian ini
menyimpulkan bahwa kebijakan
pengelolaan hutan produksi lestari
(PHPL) yang diterapkan di Kalimantan
Timur adalah sebagai berikut :

1. Bahwa kebijakan PHPL di Kalimantan Timur belum efektif, di mana sistem administrasi dalam pelaksanaan PHPL kurang berfungsi sebagai sistem pengendalian intern (SPI) guna menjamin terlaksananya Kebijakan Pengelolaan Hutan Alam Produksi Lestari (PHPL) di lapangan. Sehingga kelemahan kebijakan dari administrasi tersebut mengakibatkan hilangnya hak-hak Negara/ berupa Pedapatan dari hasil pengusahaan hutan lestari, hilangnya hak masyarakat berupa kelestarian lingkungan dan pekerjaan, dan hancurnya ekosistem, serta kemerosotan dunia usaha kehutanan lestari secara terus menerus. Kelemahan administrasi dalam pelaksanaan (operasi) kebijakan PHPL lemah dalam hal sebagai berikut:

a. Fungsi-fungsi organisasi pengusahaan kehutanan masih belum efektif. Lembaga pengawas seperti LPI (Lembaga Pengawas Independen), belum efektif mengaasi, lembaga independen pengawasan serti BPK, KPK belum difungsikan dalam ikut mengawasi usaha kehutanan.

b. Lemahnya pengawasan berakibat penyimpangan dalam usaha kehutanan baik secara pengelolaan adminitrasi dilakukan oleh banyak pihak terkait dan penegakan hukum dalam usaha kehutanan lemah.

2. Bahwa kebijakan teknis pebudidayaan hutan (silvikultur) PHPL yang berlaku yakni TPTI (Tebang Pilih Tanam Indonesia) maupun TPTII (Tebang Pilih Tanam Indonesia Intensif), yang sebenarnya belum memenuhi kriteria kelayakan mewujudkan hutan produksi lestari, karena:

3. Sebenarya Kebijakan PHPL baik silvikultur TPTI maupun TPTII 
secara teknis cukup layak mewujudkan PHPL, jika diterapkan secara penuh sesuai prosedur yang ada. Kurang dilaksanakannya PHPL lebih banyak karena faktor ekonomis, seperti pertimbangan biaya dan lemahnya pengawasan pemerintah. Banyaknya biaya transaksi (pada birokrasi) juga mendorong tidak dilaksanakannya teknik silvikultur

4. Kurang berhasilnya TPTI maupun TPTII terutama karena tidak diterapkannya kebijakan sebagaimana mestinya di lapangan. Tidak diterapkannya TPTI maupun TPTII karena terkait dengan kesimpulan pertama, yakni persoalan administrasi dalam pelaksanaan PHPL yang lemah.

\section{SARAN}

Untuk efektivitas penerapan kebijakan PHPL di Kalimantan Timur peneliti menyarankan sebagai berikut:

1. Di era otonomi daerah Pemerintah Daerah hendaknya diberi hak mengembangkan sistem PHPL sendiri dengan administrasi dan kebijakan silvikutur PHPL yang sesuai dengan kondisi sosial budaya dan lingkungan alam daerah untuk diusulkan kepusat.
2. Sistem Administrasi PHPL Daerah dilaksanakan di bawah kendali Pemerintah Daerah dengan dukungan sistem Organisasi/Kelembagaan profesional sebagai berikut; (1) Oganisasi Birokrasi (Dinas Kehutanan) sebagai regulator, (2) Organisasi Korporasi (BUMD Kehutanan) sebagai administrator, (3) Unit-Unit IUPHHK terpadu dalam kawasan KPHAP (Kesatuan Pengelolaan Hutan Alam Produksi) sebagai operator. Sistem Administrasi kebijakan PHPL yang ada hendaknya dibangun memenuhi unsur-unsur Sistem Pengendalian Intern (SPI) untuk menciptakan transparansi dan akuntabilitas sebagai berikut; (1) Struktur organisasi yang membagi setiap fungsi; (2) Pemisahan tanggungjawab fungsional; Sistem wewenang dan prosedur pencatatan memberikan keamanan transaksi; (4) Praktek yang sehat sesuai standar prosedur operasi; dan (5) penempatan pejabat, birokrat, dan petugas profesional sesuai tanggungjawabnya.

3. Hendaknya pemerintah pusat merevisi untuk menyempurnakan sistem administrasi kebijakan PHPL. 
Penyempurnaan mulai sistem organisasi/birokrasi, korporasi dan pengorganisasian unit-unit operasi IUPHHK dan kelembagaan terkait bisnis kehutanan dengan memisahkan secara profesional fungsi birokrasi, fungsi korporasi dan fungsi operasi usaha kehutanan.

4. Hendaknya kebijakan PHPL di Indonesia yang akan datang lebih mengembangkan alternatif pengelolaan hasil hutan bukan kayu dan jasa-jasa kehutanan yang tidak merusak ekosistem hutan. Usaha kehutanan bukan kayu seperti usaha hutan wisata (Eco-Tourism), jasa lingkungan, perdagangan karbon dengan mekanisme REDD (Reducing Emision Degradation and Deforestation) dan lain sebagainya, yang akan mendatangkan manfaat lebih besar, baik secara ekonomi, ekologi maupun sosial.

\section{DAFTAR PUSTAKA}

FWI (Forest Wacht Indonesia). 2001. Potret Keadaan Hutan Indonesia. http://fwi.or.id/wp.content/upload s/2013

Kartodihardjo, Hariadi. 2012. Studi Kelayakan Proyek. UPP YKPM:Yogyakarta.

Mulyadi. 2009. Sistem Akuntansi. Salemba Empat: Jakarta

Suharjo, Bambang Heru. 2007. Studi Kelayakan Proyek. Penerbit CV Andi: Yogyakarta.

Suparna,

Nana. 2013. http://m.bisnis.com/industri/read

Sutisna, Maman. 2005. Silvikultur Hutan Alami Indonesia. Direktorat Pembinaan Penelitian dan Pengabdian pada Masyarakat, Direktorat Jenderal Pendidikan Tinggi, Universitas Mulawarman, Samarinda.

Sutisna, Maman.,2008. Usaha Kehutanan Nirkayu di Hutan Negara dan Hutan Milik. Fakultas Kehutanan Universitas Mulawarman, Samarinda.

Zulkifli, Hasan. 2012. Sisa Hutan Indonesia 45 juta ha. www.m.republica.co.id 